\title{
New literacies in language learning and teaching: Selected papers from EUROCALL 2003
}

University of Limerick, Limerick, Ireland, 3-6 September 2003

\author{
LIAM MURRAY \\ University of Limerick, Limerick, Ireland \\ (email:Liam.Murray@ul.ie)
}

Contained within this issue is a selection of papers presented at the 2003 annual EUROCALL Conference, hosted during September in Limerick, Ireland. This was the second time that Ireland had the privilege of welcoming EUROCALLers, the first being the conference at Dublin City University in 1997 organised by Françoise Blin. The theme of EUROCALL 2003, "New literacies in language learning and teaching", aimed to focus attention on the changing concepts and practices concerning literacy brought about by technological developments, particularly in relation to language learning and teaching. Sub-themes focused on the changes in practices involving literacy brought about by the World Wide Web; the need to re-interpret current teaching paradigms; the relationship between the more "traditional" language skills and the "new literacies"; interactivity, learner interaction, and feedback; and spoken and written corpora in language teaching and learning. This last theme re-introduced to EUROCALL an important research area which had been well represented in the early days of the association, and has led directly to the creation of a new SIG within the association in March 2004.

The keynote speeches, while not included in this volume, deserve special mention as they served to situate the themes of the conference in a broader context. Professor Michael McCarthy, who is Professor at the University of Nottingham, the University of Limerick and Penn State University, introduced the corpus strand with a talk entitled "Spoken corpora and methodology". Drawing on spoken British and American English corpora, he argued that there is a need to move away from presentational modes of teaching the language system towards new paradigms rooted more firmly in awarenessraising and induction. "Literacies, Technologies, and Learning Communities: Speaking and writing in the virtual classroom" was the title of the plenary lecture by Robin Goodfellow, The Open University, UK. He stressed the need to draw attention away from the supposed newness of new electronic literacy practices, and re-focus it on the social nature of online literacy events. He concluded that "the challenge of literacy in the age of technology is not so much about how to equip learners with the skills to use modern media, but rather is about how to help us all - learners, teachers, course 
designers, educational managers - to understand the kinds of social action that are played out through text in the new virtual learning environments". The third keynote speaker, Professor Dieter Wolff, Bergische Universität Wuppertal, chose the theme "Web-based teaching and learning: a research perspective". Based on a presentation of Web-based introductory courses in Linguistics and Applied Linguistics, he concluded that in order to be successful Web-based courses should be blended or hybrid, including face-to-face interaction as well as virtual modules.

We begin this issue of ReCALL with pedagogues, as O'Dowd and Eberbach describe their research on the roles, demands and challenges for teachers involved in a telecollaborative exchange for language learners from Ireland and Germany. In the second paper, Pérez Basanta describes the creation, design and delivery of ADELEX, a Webbased course aimed at improving learners' vocabulary acquisition with additional emphasis accorded to increasing learner autonomy and assessing their lexical competence. Cushion then tackles the important and often ignored problem of storing and reusing language exercises that have been created in different formats. As a possible solution, he examines the potential of XML-based technologies which offer greater interoperability and access to pedagogic materials for teachers by pooling resources in a common XML standard defined data storage format. Once the standards have been defined and the teaching resources pooled, then excitingly for all researchers and practitioners in CALL, the road is left open for us to move online CALL into more imaginative areas.

Greenman, in her paper, shows us research on refined voice and text coaching with feedback for doctoral students and describes three production models that are currently in use at KULeuven, adding a central discussion on greater model development integration. In the fifth paper, Kiernan and Aizawa tackle the question of using cell phones in language learning, given their increasing functionality. These researchers concentrate on three functions in particular: text messaging, e-mail and, naturally, speaking. They report on the advantages as well as the disadvantages of using mobiles and call for further empirical research in this promising area. Another promising area was revealed by Hughes and McAvinia who examined the predilections of a large number of Secondary School aged pupils when reading Web content in order to design 'taster' courses to promote greater foreign language learning and learn more about current student use of the Web and the design of Web sites. On a similar theme, but this time with Third Level students, Rosell-Aguilar also looks at student perceptions of the Web. However, he prefers to concentrate on those elements that inform the student websearch process in general and especially in relation to set content and reading exercises.

Brett reports on his ongoing research into the acquisition and production of vowel sounds by adult learners of a second language within the development of a tool which offers real time feedback to the learner when attempting vowel pronunciations. Campbell, in the eighth paper, relates the pedagogical challenges of using and expanding a durable WebCT-based translation course and explores the use of an innovative colour-coding system of error analysis with comments intended to promote learner reflection during the translation process. SLA output theory and CALL are given particular attention by Leahy who explores a task-based setting for students, asking and answering somewhat pertinent questions on SLA and the acquisition of content and also whether students may focus on language form. Within the tenth paper here, Ros i Solé 
and Mardomingo present their tested TRAYECTORIAS tool, which offers a new model for online task-based learning, taking account of learner autonomy, new reading processes with new literacy models and constructivist approaches to knowledge acquisition.

The co-organiser of EUROCALL 2003 at Limerick, Chambers is one of the two authors along with O'Sullivan of the paper on the potential of an emerging new type of literacy known as corpus consultation which promotes the use of authentic materials and the greater development of learner autonomy amongst advanced language learners. It offers sound evidence that the employment of this type of literacy helps in the context of interactive feedback especially where traditional resources are of limited use. In the twelfth paper, we return to pronunciation problems with Yasushi's system aimed at helping Japanese students of English in an autonomous learning context. The need for such a system is further justified by the interesting report that these students tend to spend time on aspects of pronunciation that do not discernibly affect their understanding by a native speaker of English. Orsini-Jones relates the outcomes - both positive and negative from an action research project involving staff and students in the teaching and acquisition of ICT skills and language specific ones within a WebCT environment. Amongst her several conclusions, we may note that simply using technology in our teaching does not necessarily lead to learner autonomy.

In the final paper from the Conference, Corda and Jager present a more CALL-dedicated though not exclusive VLE known as ELLIPS, which was developed collaboratively and employed widely in Dutch Higher Education Institutions. ELLIPS concentrates on grammar, listening and pronunciation skills but includes additional features such as extensive feedback for attempted exercises, a learner tracking and performance recording system and streaming audio and video.

Also in this issue, there is one regular paper included from Felix offering the results from a large survey of Secondary School pupils' perceptions of Web-based learning which were, on the whole, positive. Interestingly, and reassuringly, pupils expressed a preference for teacher delivery, with the Web being seen as a valuable support.

Finally I would like to thank the EUROCALL Executive Committee for their invaluable advice and assistance, especially former conference organisers Françoise Blin and Peppi Taalas, but most of all the patient, always responsive and indefatigable June Thompson. A celebratory yet sad event which took place at EUROCALL 2003 was a short ceremony marking the tenth anniversary of the Association. As the headquarters moved to Limerick on 1 October 2003, conference participants thanked Graham Chesters and June Thompson for their vision and hard work which has made the Association the exemplary and highly professional body that it has become today.

Thanks are due to the following colleagues who acted as additional referees for this issue:

Jean Conacher, University of Limerick, Limerick, Ireland

Laurence Durroux, University of Montpelier, France 